Institute of $\mathbf{F}_{\text {ood and }} \mathbf{A}_{\text {gricultural }} \mathbf{S}_{\text {ciences }}$

\title{
Agroforestry: Options for Landowners ${ }^{1}$
}

\author{
Sarah W. Workman, Alan J. Long, Soumya Mohan, and Martha C. Monroe ${ }^{2}$
}

Agroforestry is growing trees with crops and/or with animals in combinations that will benefit farmers, forest landowners, and communities. By mixing these different components on the same site, agroforestry practices can provide a variety of traditional products and additional income as well as conservation, aesthetic, and environmental benefits. Perhaps the most important aspect of agroforestry is its diversity of land management options for producing income and protecting natural resource values.

Agroforestry is part of an intentional land management approach to optimize biological interactions between trees, shrubs, crops, and animals. The multiple products generated from these complementary mixtures are available at different time intervals, can utilize space effectively, and can efficiently cycle nutrients. These diverse combinations also help buffer the risk of income loss due to price variability or crop failure. Opportunities for expanding the use of agroforestry practices, and the benefits that result, are increasing rapidly in the southern United States.

\section{Agroforestry: A Tool for Land Management in the Southeast}

Crop and pasture lands occupy significant portions of land area in the southern U.S. and forests occupy more acres than all crop and pasture land combined. However, both farm and forestland are being converted to other uses, increasing the pressure for more efficient production on the remaining croplands. For productive lands, the costs of remaining in business are often increasing as well as making it all the more important to become more profitable. Tree-crop and tree-forage combinations that produce regular cash flows and protect erodible sites can be important to optimizing land use.

Particular agroforestry designs depend on landowner objectives and can emphasize any combination of timber, row crops, livestock, fruit crop, firewood, wildlife, and recreational habitat. At the same time, agroforestry systems guard against loss of top soil or applied fertilizer, enhance water infiltration and ground water recharge, provide energy savings through use of shade, and create an attractive and healthier landscape. Additional features can be incorporated to promote recreational,

1. This document is FOR 104, one of a series of the School of Forest Resources and Conservation, Center for Subtropical Agroforestry (CSTAF), Institute of Food and Agricultural Sciences, University of Florida. This publication was produced by the University of Florida with assistance from a grant from USDA/CSREES/IFAFS. For more information contact CSTAF, P.O. Box 110831, Gainesville, FL 32611, (352) 846-3496, http://CSTAF.ifas.ufl.edu. First published August 2002. Please visit the EDIS Web site at http://edis.ifas.ufl.edu.

2. Sarah W. Workman, Visiting Assistant Professor, Center for Subtropical Agroforestry. Alan J. Long, Associate Professor. Soumya Mohan, Graduate Student. Martha C. Monroe, Assistant Professor, School of Forest Resources and Conservation, Cooperative Extension, Institute of Food and Agricultural Sciences, University of Florida, Gainesville, FL 32611.

The Institute of Food and Agricultural Sciences is an equal opportunity/affirmative action employer authorized to provide research, educational information and other services only to individuals and institutions that function without regard to race, color, sex, age, handicap, or national origin. For information on obtaining other extension publications, contact your county Cooperative Extension Service office. Florida Cooperative Extension Service/Institute of Food and Agricultural Sciences/University of Florida/Christine Taylor Waddill, Dean. 
educational, and other options that diversify enterprise opportunities.

Agroforestry fits well with plans for alternative or secondary enterprises. Trees or shrubs are valued for production of timber and/or nontimber products such as firewood, nuts, or mushrooms. They may also be deliberately managed for windbreaks, for wildlife habitat, as shade for livestock, or for stream protection. Crops may be sold on the open market, retained for personal use, or used for livestock forage or green manure. Adopting agroforestry practices, like other innovations, requires special planning and understanding of the disadvantages as well as benefits of the practices as they relate to the overall production and management objectives. For example, markets may not be well established for some products, new knowledge or labor may be needed, or special equipment may be necessary for cultivation or harvest of new crops.

This fact sheet outlines some of the key traits of agroforestry, then briefly describes common practices that are used for multiple output management in the Southeast. Additional fact sheets provide details and regional examples for each of these major agroforestry practices.

\section{Key Traits of Agroforestry}

Agroforestry designs vary from combinations of hay with pecan trees, to goats with pine trees, and vegetables with citrus. These agroforestry combinations are distinguished from traditional agriculture or forestry by a few key traits. First, an agroforestry design is intentionally managed as a whole system with intensive cultural practices for more than one crop and/or animal. Second, the landowner uses interactions between trees, crops, and/or animal components to achieve particular objectives while protecting resources. For example in a silvopasture design, rows of browse shrubs could be incorporated along tree or fence lines and combined with border plantings around parcels to screen dust or serve as shade and wildlife habitat. Thus, the design components are structurally and functionally combined into a single management unit with multiple objectives.

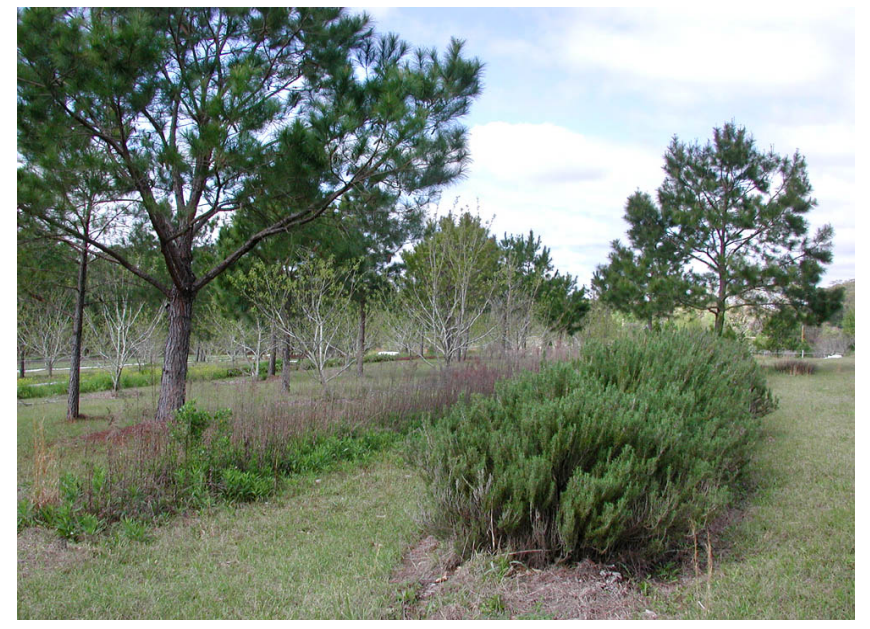

Figure 1. Persimmons and rosemary combined with pines.

\section{Agroforestry in North America: Some Common Practices}

Alley Cropping: This practice consists of planting herbaceous or other crops between widely spaced tree rows. The wide alleys are easily farmed with standard equipment. Cash crops grown in the alley could be hay, corn, cotton, squash, other vegetables, or berries. While the tree crop matures the alley crops provide annual income and, depending on the level of shade provided by the tree row over time, the alley crop could be changed to match the changing conditions.

Trees can be planted in single or multiple tree rows and thinned for pulpwood, fencing, or firewood while they are small diameter. Larger trees may be harvested for lumber or other high value products. Preferred tree species are pines and hardwood such as pecan, ash, oak, persimmon, cherry, or poplar. Nuts and fruits produced by pecan, chestnut, and persimmon provide an intermediate income, often coming into full production about the time alley crop production is shaded out.

Fruiting or ornamental shrubs (e.g. blueberry, huckleberry, bayberry) can be established instead of trees, or grown in the alleys instead of crops for fruit or floral industry products (e.g. decorative boughs). Ground cover and fruit-bearing shrubs next to trees can provide wildlife travel lanes, food, and cover. This practice improves financial returns by more intensive and diversified use of space with combinations of annual and perennial crops. The practice, while diversifying products and income 
sources, may also decrease the total production of any single crop because of the space and resources shared with other crops.

Forest Farming: This practice utilizes forested areas for producing specialty crops that are sold for medicinal, ornamental, or culinary uses. Specialty crops that tolerate partial shade include herbs, wildflowers, ferns, saw palmetto, mushrooms such as morels and shiitake, and fruits such as plums, pawpaw, wild berries, or mayhaw. Other nontimber products that can be collected and marketed from shaded conditions are pine straw, honey, and crafting materials. While many of these products have traditionally been collected from natural sources, in forest farming, intentional management of the crop plants and the overstory trees can increase specialty crop productivity. The overstory trees can also be harvested for timber products, either during regular forest farming operations or in a final harvest. Specialty products produced in forest farm designs can supplement family income, increase product diversity on the site, and provide short-term cash.

Riparian Buffer Strips: This practice is already common in the Southeast since forest landowners maintain vegetation buffer strips along streams according to Forestry Best Management Practices (BMPs) in each state. Strips of woody perennial and annual vegetation in streamside management zones play a key role in maintaining stream water quality. They hold water, reduce runoff, trap sediment, and help control stream bank and in-channel erosion. They also help rectify some of the most adverse effects of present day agriculture by trapping runoff containing agrochemicals and animal wastes.

The width of a riparian forest buffer depends on specific forestry or agricultural BMP guidelines in each state, the condition of the waterway/wetland, site characteristics such as slope, and the type of soil. Landowner objectives may call for buffer strips wider than BMP guidelines, as streamside and bottomland forests are productive places for a variety of nontimber forest products and habitat for many wildlife and fish species. Buffer strips can be managed intensively by planting strips of perennial vegetation between crop fields and water, often in multi-layer patterns, where unprotected waterways cross agricultural land.
The trees, shrubs, and grasses that are suggested for use in riparian buffer strips and streamside management zones need to be tolerant of occasional flooding or wet soil conditions. Those with a well-developed, shallow root system will be more efficient in uptake of nutrients and agrochemicals. Tree species used in these buffers range from cypress and tupelo to willows, poplars, ash, oaks and maples. Shrubs can include wax myrtle, buttonbush, viburnum, gallberry or other hollies. While switchgrass is often used for a grass buffer strip, any number of native species can also be used in the grass/herb component.

Silvopasture: Silvopasture intentionally combines trees with livestock and forage production. The Southeast leads the nation in development of this practice because good growing conditions can be maintained for both timber and livestock production on the same site. Benefits to the farmer include income generation while converting from crop to timber (or vice versa), improvement in water quality, wildlife habitat, and soil erosion control. In the Southeast, these systems vary from rotational grazing in pine forests or plantations, to intentional grazing under hardwoods and pecan groves.

For silvopasture, trees are planted or thinned to provide sufficient light for good forage production. High value timber species can be intensively managed in widely spaced rows, and are most often grouped in double or triple rows to improve form (double-rows $8 \mathrm{ft}$ apart, $4 \mathrm{ft}$ between trees within a row, and $40 \mathrm{ft}$ to next set of trees). Many landowners have adopted these systems using bahiagrass as a summer forage with clovers, rye, or ryegrass as winter forage. Some orchards and woodlots incorporate rotational grazing with cattle, goats, sheep, or other livestock/poultry.

Windbreaks: Most common in the Midwest and Great Plains, windbreaks are rows of trees around homesteads, farms, and fields that are managed as part of crop or livestock operations. They protect soils, animals, and crops; help reduce dust, odor, and noise; and provide cover and food for wildlife. Windbreaks help prevent frost damage and have increased crop yields as much as 20 percent in some areas. In the Southeast they are important sources of 


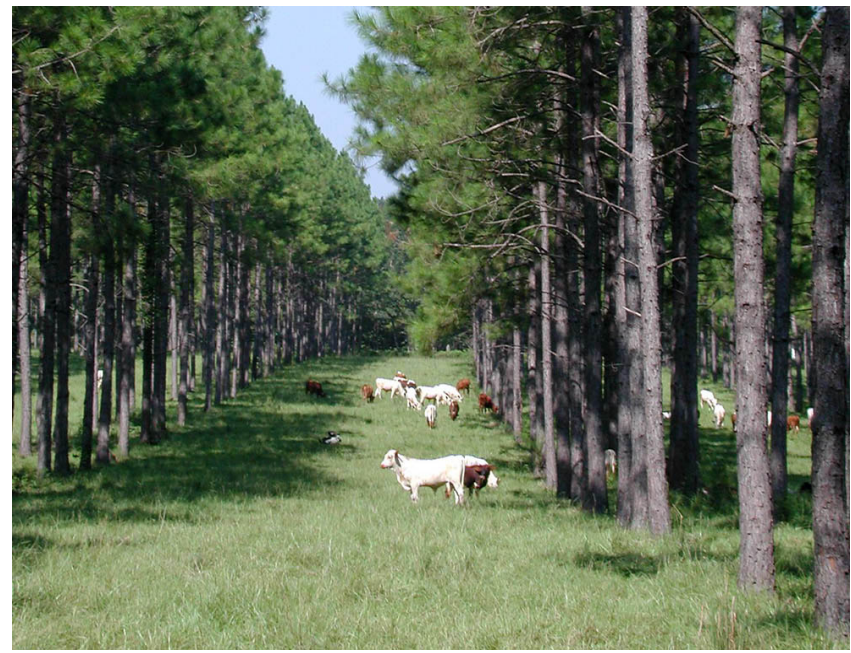

Figure 2. Silvopasture: managing cattle and forage with slash pine.

shade for livestock during hot summer months. Even a single row of pine trees around a pasture border will furnish this protection. More typically, windbreaks are planted as multiple rows of mixed species.

In areas of high humidity or less erodable soils, low-density windbreaks provide multiple benefits without promoting fungal or pest problems and may serve to block spread of windborne pests.

Windbreaks are also planted to protect buildings, work areas, roads, and community spaces. Just about any tree and shrub species can be used to establish windbreaks, although each should be evaluated for the planting site and project objective. Evergreens such as eastern redcedar and pines are considered ideal for year round protection. Other effective windbreak species are boxelder, cottonwood, and shrubs such as crabapple, hawthorns, laurelcherry, hollies, and flowering ornamentals.

\section{Agroforestry Combinations Make Sense}

Agroforestry has the potential to improve the diversity, quality, and in some cases perhaps even yield of crops. These improvements may enhance cash flows and provide good return for the labor invested. Practices can be used to moderate temperature or other environmental stress and provide settings for recreational uses. Compared to more traditional plantation forestry or agricultural systems, adopting agroforestry techniques as forest or farm land management options provides opportunities to expand production, diversify incomes, and enhance non-market benefits such as soil and water conservation and wildlife habitat.

Adoption of the practices requires planning and management to successfully integrate different trees, crops, and animals. Watch for future fact sheets that will explain each of the agroforestry practices in more detail and others about resources and contacts for agroforestry information. 